Original Article

\title{
CYTOTOXIC EFFECTS OF ETHYL ACETATE FRACTIONS FROM SECONDARY METABOLITES OF STREPTOMYCES SP. GMY01 ON HUMAN BREAST CANCER MCF7 CELL LINES
}

\author{
SISTA WERDYANI ${ }^{*}$, NASTITI WIJAYANTI ${ }^{2}$, ANNISA FITRIA ${ }^{1}$, SARI RAHMAWATI ${ }^{1}$
}

1Department of Pharmacy, Universitas Islam Indonesia, ²Department of Animal Physiology, Faculty of Biology, Universitas Gadjah Mada, Yogyakarta, Indonesia

Email: sista.werdyani@uii.ac.id

Received: 05 Feb 2017 Revised and Accepted: 18 Apr 2017

ABSTRACT

Objective: This research aimed to fractionate the ethyl acetate extract from secondary metabolites of Streptomyces sp. GMY01 and to identify which fraction contains cytotoxic active compounds against human breast cancer MCF7 cell lines.

Methods: Secondary metabolites were obtained from fermentation of Streptomyces Sp. GMY01 for 15 d. The supernatant containing these secondary metabolites was extracted through partition using ethyl acetate as the solvent. Fractionation of the ethyl acetate extract was conducted via column chromatography using silica gel as the solid phase while the gradient mobile phase consisted of n-hexane, ethyl acetate, and methanol. The cytotoxicity of each fraction was calculated using MTT-assay.

Results: The ethyl acetate extract could be separated into 9 fractions using column chromatography. The cytotoxic effect of each fraction differed from each other. The smallest $\mathrm{IC}_{50}$ value was obtained from fraction 4 . Further investigation should be conducted to discover the active anticancer compound. The active compound with cytotoxic effect was found in fraction 4 because of the highest IC 50 value.

Conclusion: This fraction is potential to be investigated more deeply as anticancer, especially for breast cancer.

Keywords: Streptomyces Sp. GMY01, MCF7, cytotoxicity, MTT

(C) 2017 The Authors. Published by Innovare Academic Sciences Pvt Ltd. This is an open access article under the CC BY license (http://creativecommons.org/licenses/by/4.0/) DOI: http://dx.doi.org/10.22159/ajpcr.2017v10s3.21351

\section{INTRODUCTION}

Cancer is one of the deadliest diseases in the world. Cancer death rate remains high, reaching about 8.2 million people worldwide in 2012 and 347,792 people in 2013 in Indonesia. Breast cancer is one of the cancers with the highest prevalence in Indonesia in 2013, amounted to $0.5 \%$. Yogyakarta (a special region in Indonesia) has the highest prevalence of cancer in general and breast cancer in particular among all provinces in Indonesia, which is about $4.1 \%$ for all cancers and $2.4 \%$ for breast cancer $[1,2]$.

The persistently high rate of cancer incidence has encouraged researchers to discover anticancer compounds, especially for breast cancer. Mitomycin $\mathrm{C}$ is one of the drugs used in the chemotherapy of various types of cancer [3]. At first, the compound was isolated from the extract of secondary metabolites of gram-positive bacterium Streptomyces lavendulae growing on land [4]. Farida (2008) then isolated marine actinomycetes named Streptomyces sp. GMY01 [5, 6]. The sequence analysis of this isolate's NRPS apparently showed a similarity index by $79 \%$ relative to Streptomyces lavendulae [7]

This high similarity index value leads to an idea that Streptomyces sp. GMY01 can also produce anti-cancer compounds. Furthermore, the ethyl acetate extract from secondary metabolites of Streptomyces sp. GMY01 shows cytotoxic effects on human breast cancer MCF7 cell lines. The cytotoxicity of this extract is indicated by the $\mathrm{CC}_{50}$ value of $118 \mathrm{ng} / \mathrm{ml}$ in T47D cell lines and $60 \mathrm{ng} / \mathrm{ml}$ in MCF7 [7]. However, the active compound responsible for the cytotoxic effect of this ethyl acetate extract has not been discovered. This study was therefore conducted to identify which fraction has the biggest cytotoxic effect on MCF7 cell lines. The cell culture used as a test model in this study was MCF-7 cells because it was not invasive and was a model system of positive ER $\alpha$ in breast cancer [8].

\section{MATERIALS AND METHODS}

Materials

An isolate of Streptomyces sp. GMY01 was obtained from the Microbiology Department of the Agriculture Faculty of Gadjah Mada University. The materials for cytotoxic assay were MTT (3-(4,5dimethylthiazol-2-yl)-2,5-diphenyltetrazolium bromide) (Sigma Chemical), DMSO (Dimethyl Sulfonic Acid) (MP Biomedicals), DMEM (Dulbecco's Modified Eagle Medium) (Gibco), FBS (Fetal Bovine Serum) (Gibco), PBS (Phosphate Buffer Saline) (Gibco), Trypsin (Gibco), Fungizone (Gibco), and Penstrep (Gibco).

Fermentation, extraction, and fractionation of Streptomyces sp. GMY01

The fermentation of Streptomyces sp. GMY01 in SNB (Starch Nitrate Broth) medium was carried out for $15 \mathrm{~d}$ to obtain secondary metabolites. Centrifugation of the fermentation medium was then performed to separate the supernatant containing secondary metabolites from the pellet containing Streptomyces sp. GMY01 cells. Active compound was extracted from the supernatant using partition method with ethyl acetate as the extraction solvent. The ethyl acetate extract was then fractionated through column chromatography using silica gel as the stationary phase along with the gradient mobile phase from n-hexane, ethyl acetate, and methanol. The fractions profiles were identified via TLC (Thin Layer Chromatography).

\section{Cytotoxicity assay}

The comparison of cytotoxicity between fractions was assessed using MTT Assay. The MCF7 cells were grown in DMEM medium containing $10 \%$ FBS, $1 \%$ Penstrep, and fungizone $0.5 \%$ in flasks stored in a humidified incubator $\left(5 \% \mathrm{CO}_{2}\right)$ at $37^{\circ} \mathrm{C}$. The Cytotoxicity 
assay was performed in 96-well plates (Iwaki). The MCF7 cells cultured on each well consisted of $5 \times 10^{3}$ cells. These well plates were then stored in an incubator for $24 \mathrm{~h}$. After incubation, the culture medium was discarded and the MCF7 cells were treated with ethyl acetate extract and fractions. The concentration was adjusted to the results of the optimisation (table 1). Incubation of this treatment was also done for $24 \mathrm{~h}$. MTT was then added into each well as much as about $0.5 \mathrm{mg} / \mathrm{ml}$ and stored for $4 \mathrm{~h}$ at $37^{\circ} \mathrm{C}$. SDS 10 $\%$ in $0.01 \mathrm{HCl}$ was also added to each well after incubation to stop the reaction between the cells and MTT. This step lasted for $24 \mathrm{~h}$ at $37^{\circ} \mathrm{C}$ and was protected from light. After incubation, the well plates were shaken and the absorbance was measured for each well using ELISA reader at $\lambda 595 \mathrm{~nm}[9]$.

\section{Data analysis}

The absorbance value of each well was calculated as the percentage of viable cells using the following formula.

Percentage of viable cells $=(\mathrm{B}-\mathrm{C} / \mathrm{A}-\mathrm{C}) \times 100 \%$, in which $\mathrm{A}, \mathrm{B}$, and C were the absorbance of cells in the control group, treatment group, and medium control group, respectively. The cytotoxic effect was compared from $\mathrm{IC}_{50}$ value using the probit analysis.

Table 1: Concentration of each extract and fraction

\begin{tabular}{ll}
\hline Treatment & Concentration \\
\hline Ethyl acetate extract; Fraction 4 & $50 ; 25 ; 12.5 ; 6.25 ;$ and $3.125 \mu \mathrm{g} / \mathrm{ml}$ \\
Fraction $1,2,5,8,9$ & $200 ; 100 ; 50 ; 25 ;$ and $12.5 \mu \mathrm{g} / \mathrm{ml}$ \\
Fraction 3 and 6 & $1000 ; 500 ; 250 ; 125 ;$ and $62.5 \mu \mathrm{g} / \mathrm{ml}$ \\
Fraction 7 & $300 ; 150 ; 75 ; 37.5 ;$ and $18.75 \mu \mathrm{g} / \mathrm{ml}$ \\
\hline
\end{tabular}

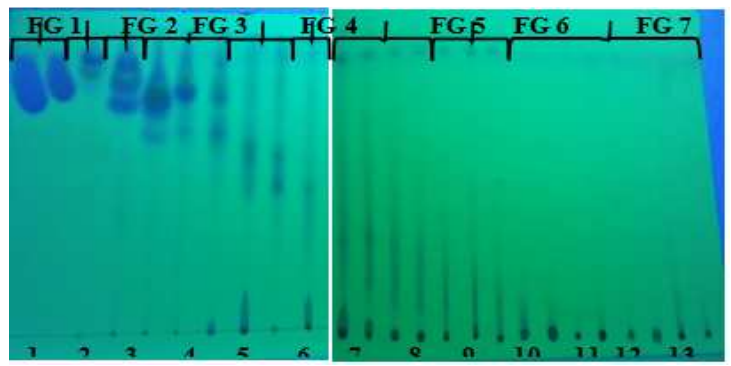

Fig. 1: TLC results observed under UV 254 for each fraction

\section{RESULTS AND DISCUSSION}

Fermentation, extraction, and fractionation of Streptomyces sp. GMY01

The fermentation process was selected from the formation of secondary metabolites because of some advantages, such as: the ability to form complex molecules impossibly made through chemical reactions, a larger number of products, and the simpler requirement of a low temperature and close-to-neutral $\mathrm{pH}$ [10].

The fermentation time in this study was also adjusted to previous research, in which $15 \mathrm{~d}$ was assumed adequate to have formed secondary metabolites $[5,7,11-13]$. The preferred method of fractionation was the gravity column chromatography because it does not require expensive equipment and is simple to do [14]. The profile of each fraction was determined by TLC (fig. 1). The fractions with similar profile were then combined as one fraction. For example, fraction 1 and 2 were combined as fraction 1 . After combination, 9 fractions were obtained. The percent yield for each fraction is shown in table 2 below.

\section{Cytotoxicity assay}

The $\mathrm{IC}_{50}$ value (table 3 ) for each fraction was calculated from the percentage of cell viability (fig. 2). The number of viable cells could also be observed by comparing the morphology of each cell. The two parameters showed that the higher the dose the less the number of living cells.

Table 2: Percent yield for each fraction

\begin{tabular}{llll}
\hline Fraction & Component & Weight (g) & Percent yield (w/w) \\
\hline 1 & Fraction 1 and 2 & 0.3068 & $30.68 \%$ \\
2 & Fraction 3 & 0.018 & $1.8 \%$ \\
3 & Fraction 4 & 0.0187 & $1.87 \%$ \\
4 & Fraction 5-7 & 0.0879 & $8.79 \%$ \\
5 & Fraction 8 and 9 & 0.0792 & $7.92 \%$ \\
6 & Fraction 10 & 0.0452 & $4.52 \%$ \\
7 & Fraction 11-14 & 0.1364 & $13.64 \%$ \\
8 & Fraction 15-17 & 0.0541 & $5.41 \%$ \\
9 & Fraction 18-25 & 0.2248 & $22.48 \%$ \\
\hline
\end{tabular}

Table 3: $\mathrm{IC}_{50}$ value for each fraction

\begin{tabular}{ll}
\hline Treatment & IC $\mathbf{5 0}$ value $(\boldsymbol{\mu g} / \mathbf{m l})$ \\
\hline Fraction 1 & 270.15 \\
Fraction 2 & 444.52 \\
Fraction 3 & 221.15 \\
Fraction 4 & 85.73 \\
Fraction 5 & 1450.96 \\
Fraction 6 & 532.15 \\
Fraction 7 & 425.54 \\
Fraction 8 & 1546.73 \\
Fraction 9 & 357.13 \\
\hline
\end{tabular}




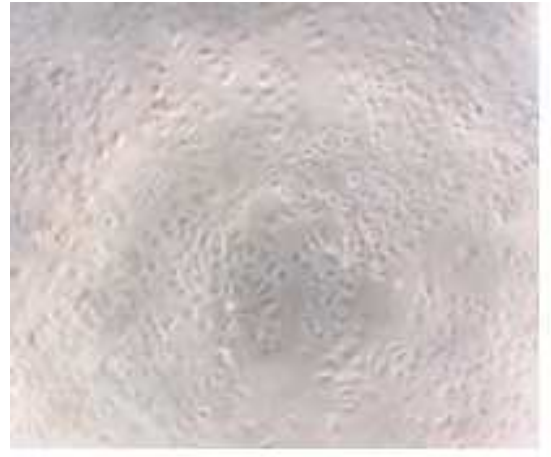

(A)

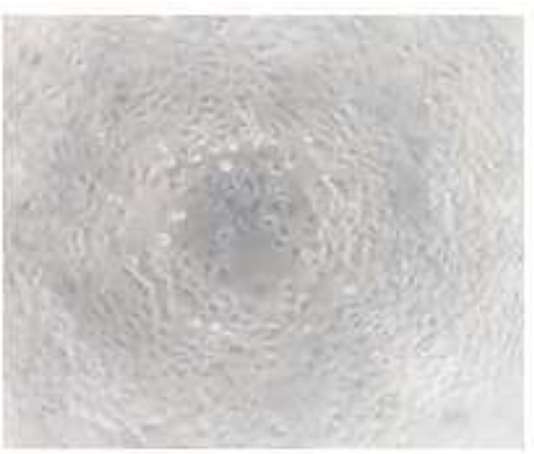

(B)

Fig. 2: Cell morphology of MCF7 after incubation with fraction 4 in the highest concentration (A) and in the lowest concentration (B)

The highest cytotoxic activity was in fraction 4 because of the smallest $\mathrm{IC}_{50}(85.73 \mu \mathrm{g} / \mathrm{ml})$. This value can be smaller if we continue to separate the active compound contained in fraction 4 . The compound profiles compound of the fractions (fig. 1) indicated that fraction 4 consisted of more than one compounds. It is still possible to be separated with fractionation; therefore, further fractionation is suggested for fraction 4 and so is further MTT assay for each sub-fraction. The $\mathrm{IC}_{50}$ value will be smaller for the sub fraction. Moreover, treatment for other cell lines besides MCF-7 is also recommended to be done because anti-cancer compound should be active for all cancer cells.

\section{CONCLUSION}

The active compound that has cytotoxic effects belongs to fraction 4 because of the smallest $\mathrm{IC}_{50}$ value. This fraction is potential to be further investigated as anticancer, especially in breast cancer.

\section{ACKNOWLEDGMENT}

We gratefully thank DP2M DIKTI (Directorate of Higher Education) of the Ministry of Education of Indonesia through "PUPT" 2015-2016 and DPPM UII (Universitas Islam Indonesia) through "Hibah Penelitian Pemula" for the financial support of the study. We also thank Ir. Jaka Widada, Ph. D. (Department of Microbiology, Faculty of Agriculture Universitas Gadjah Mada) for the permission to use Streptomyces sp. GMY01 as the subject of this study.

\section{CONFLICTS OF INTERESTS}

All authors have none to declare

\section{REFERENCES}

1. Balitbangkes. Basic Health Research. Indonesian Health Ministry: Jakarta; 2013.

2. WHO. Cancer; 2015: Available from: http://www.who.int/ mediacentre/factsheets/fs297/en/. [Last accessed on 30 Mar 2016].

3. Bradner WT. Mitomycin C: a clinical update. Cancer Treatment Rev 2001;27:35-50.
4. Mao Y, Varoglu M, Sherman DH. Genetic localization and molecular characterization of two key genes (mit $\mathrm{AB}$ ) required for biosynthesis of the antitumor antibiotic mitomycin C. J Bacteriol 1999;181:2199-208.

5. Farida Y. Combination methods for screening marine actinomycetes producing potential compounds as anticancer; Thesis, Gadjah Mada University; 2008.

6. Farida Y, Widada J, Meiyanto E. Combination methods for screening marine actinomycetes producing potential compounds as anticancer. Int J Biotechnol 2007;12:988-97.

7. Widowati EW. Toxic compounds in various actinomycetes GMY01 extracts against breast cancer cells T47D and MCF7, Thesis, Gadjah Mada University; 2010.

8. Sheeba JMDJ, Mohan CM, Marine H, Gauri D, Neeraj K, Mukund LA. Estrogen-regulated extracellular matrix remodelling genes in MCF-7 breast cancer cells. Gene Reports 2016;3:14-21.

9. Nugroho AE, Ikawati M, Hermawan A, Putri DDP, Meiyanto E. Cytotoxic effect of ethanolic extract fractions of Indonesia plant ficus septica burm. F. on human breast cancer T47D cell lines. Int J Phytomed 2011;3:216-26.

10. Smith JE. Biotechnology. Fifth edition. Cambridge University Press: New York; 2009.

11. Imaniar NI. Antiviral activity of secondary metabolites of the sea and land actinomycetes against dengue virus serotype- 1 , Thesis, Gadjah Mada University; 2013.

12. Supardan. Antiviral activity of secondary metabolites of actinomycetes against dengue virus serotype 3, Thesis, Gadjah Mada University; 2013.

13. Praditya DF. The potential antiviral activity of ethyl acetate extract and water extract of secondary metabolites of actinomycetes against dengue virus serotype 2 (DEN-2). Thesis, Gadjah Mada University; 2013.

14. Ghanbari K, Aghajani H, Golbabaee M, Khah EN, Nabavi SH, Koohian A. Column chromatography: a facile and inexpensive procedure to purify the red dopant DCJ applied for OLEDs. Adv Mater Phys Chem 2011;1:91-3. 